\title{
Phytochemical Screening, Toxicity, Analgesic and Anti-Pyretic Studies of Aqueous Leaf Extract of Plectranthus barbatus [Andrews. Engl.] in Rats
}

\author{
Joseph Obiezu Chukwujekwu Ezeonwumelu1,2*, Gloria Nambirige Kawooya1, \\ Aiyabalu Godwin Okoruwa ${ }^{3}$, Samuel Sunday Dare ${ }^{2,4}$, Jennifer Chibuogwu Ebosie ${ }^{1}$, \\ Ambrose Amamchukwu Akunne'1, Julius Kihdze Tanayenn',5, Bede Emeka Udechukwu ${ }^{6}$ \\ ${ }^{1}$ Department of Clinical Pharmacy \& Biopharmacy, School of Pharmacy, Kampala International University Western Campus, \\ Ishaka, Bushenyi, Uganda \\ ${ }^{2}$ Kampala International University Complementary and Alternative Medicine Research (KIUCAMRES) Group, Western Campus, \\ Ishaka, Bushenyi, Uganda \\ ${ }^{3}$ Department of Clinical Pharmacy \& Biopharmacy, School of Pharmacy, Kilimanjaro International University, Dar es salaam, \\ Tanzania \\ ${ }^{4}$ Department of Anatomy, Faculty of Biomedical Sciences, Kampala International University Western Campus, Ishaka, Bushenyi, \\ Uganda \\ ${ }^{5}$ School of Health and Medical Sciences, Catholic University in Cameroon, Bamenda, Cameroon \\ ${ }^{6}$ Department of Pharmacology and Toxicology, Kampala International University Western Campus, Ishaka, Bushenyi, Uganda \\ Email: *nduezeh@gmail.com
}

How to cite this paper: Ezeonwumelu, J.O.C., Kawooya, G.N., Okoruwa, A.G., Dare, S.S., Ebosie, J.C., Akunne, A.A., Tanayen, J.K. and Udechukwu, B.E. (2019) Phytochemical Screening, Toxicity, Analgesic and Anti-Pyretic Studies of Aqueous Leaf Extract of Plectranthus barbatus [Andrews. Engl.] in Rats. Pharmacology \& Pharmacy, 10, 205-221.

https://doi.org/10.4236/pp.2019.104018

Received: December 3, 2018

Accepted: April 21, 2019

Published: April 24, 2019

Copyright (๑) 2019 by author(s) and Scientific Research Publishing Inc. This work is licensed under the Creative Commons Attribution International License (CC BY 4.0).

http://creativecommons.org/licenses/by/4.0/

\begin{abstract}
Plectranthus barbatus is a popular tropical perennial plant with a wide variety of traditional medicinal uses in tropical Africa, Hindu, Ayurvedic and traditional medicines of Brazil and China. The whole plant and the leaves have many folkloric uses for diverse ailments including pain, heart disease, convulsions, coughs and colds, asthma, bronchitis and tonsillitis among others. This study investigated the phytochemical components, acute toxicity, analgesic and anti-pyretic activities of the aqueous leaf extract of Plectranthus barbatus locally known as Ekizeera in Uganda. The plant leaves were authenticated, collected and decoction was done according to local method. Phytochemical screening was conducted using methods outlined by Trease and Evans and Harborne to determine the components of the extract. Acute toxicity tests were conducted in rats using modified Lorke's method to determine the safety of the plant material. Analgesic studies were carried out using both a mechanical method (thermally induced pain by tail-flick) and a chemical method (formalin induced pain) in rats by administering extracts orally at 100 , 200 and $400 \mathrm{mg} / \mathrm{kg}$ of body weight. The method of Al-Ghamdi, modified for
\end{abstract}

\section{Open Access}


local laboratory setting by Adzu was adopted and used for anti-pyretic test. Decoction yielded $9.9 \%$ extract. Phytochemical screening confirmed presence of saponins, tannins, alkaloids, terpenoids and essential oils. Acute toxicity tests revealed no deaths in rats after oral treatment with up to $10,000 \mathrm{mg} / \mathrm{kg}$ of extract. Tail-flick test was non-significant $(\mathrm{p}>0.05)$ while formalin-induced pain test demonstrated significant activity $(\mathrm{p}<0.05)$ with ANOVA and student t-tests. Anti-pyretic activity was non-significant ( $\mathrm{p}>$ 0.05 ) with student $t$-test. These results suggest that the aqueous leaf extract of Plectranthus barbatus contains specific phytochemicals, has a potent dose dependent analgesic activity, no anti-pyretic activity and can be regarded as a safe medicinal plant to use traditionally, which might further be developed for conventional medical practice.

\section{Keywords}

Acute Toxicity, Analgesic, Anti-Pyretic, Plectranthus barbatus, Phytochemicals, Rats

\section{Introduction}

Globally, especially in Africa and Asia, an herbal medicine or phytomedicine or botanical medicine which is a form of traditional medicine is still in use [1]. Many indigenous communities globally have adopted plants as an integral part of life [2]. The World Health Organization estimates that $80 \%$ of the world population presently uses herbal medicine [3]. Traditional healers have for centuries been the main providers of primary health care [4] [5]. In Uganda, almost $70 \%$ of the population still depends on traditional or herbal remedies for day-to-day health care, and in some rural areas it extends as far as $90 \%$ [6]. Plectranthus barbatus [Andrews. Engl.], (Lamiaceae) with International Plant Names Index (IPNI: 157914; Bot. Repos. 10: t. 5941810), more commonly known as Coleus forskohlii [7], is a small, annual or perennial profusely branched succulent aromatic herb [8], with a wide variety of traditional uses in tropical Africa, Hindu, Ayurvedic and traditional medicines of Brazil and China [9]. It is locally used to relieve pain and fever and treat malaria in Bushenyi region of Western Uganda where it is known as "Ekizeera" in Lunyankore language. The major ethnobotanical uses are for intestinal disturbance, liver fatigue, respiratory disorders, certain nervous system disorders like pain, heart disease, convulsions, spasmodic pain, painful urination, coughs and colds, excellent expectoration, stuffy noses, asthma, chronic coughs, bronchitis, colic, flatulence, rheumatism and earaches [10]; gastrointestinal infections, purging, nausea, gastritis and intestinal spasms, the most popular use being for gastric lesions [11]; sore throats, mouth infections, tonsillitis, boils, sprains and painful swellings [9] [12]; and wounds and ringworms [12]. It is also used in treatment of colon cancer when mixed with other drugs, in body building supplement because forskolin has been found to significantly increase lean mass, bone mass 
and testosterone [13]; for tooth and gum disorders, glaucoma because it contains forskolin which reduces intraocular pressure by stimulating adenylate cyclase activity and increasing cyclic adenosine monophosphate which regulates enzymes required for cellular energy to move fluid out of the eye and increases the skin's natural resistance to burning under ultraviolet light by stimulating a tannin response when applied topically. The plant reduces urinary tract infections because forskolin enhances the ability of antibiotics to kill bacteria that normally survive [14]. It is also effective in treatment of hypertension in modern medicine [15]; since it contains forskolin which is a known cardiotonic agent [16], which explains the decrease in blood pressure of anaesthetized rat due to relaxation of vascular smooth muscle [17]. The main constituents include 8, 13-epoxy-labd-14-en-11-one diterpenoids, essential oil and abietane diterpenoids [17]. The plant produces the labdane diterpenoid, forskolin (coleonol) which increases the amount of cyclic adenosine monophosphate (cAMP) in cells and intracellular cAMP level inhibits platelet activation and degranulation, mast cell degranulation and histamine release; relaxes the arteries and other smooth muscles; increases insulin secretion, thyroid function and lipolysis [18]. Forskolin, in clinical studies, reduced intraocular pressure when it was applied to the eyes for treating glaucoma [14]. It has been shown to be a direct cerebral vasodilator. It has also been shown to effectively reverse methacholine-induced broncho-constriction in extrinsic asthmatics. Standardized coleus extracts containing forskolin ( $18 \%$ in $50 \mathrm{mg}$ ) found application in weight-loss programmes where a 12-week supplementation with forskolin did not cause weight loss, but improved body composition in men and prevented weight gain in women [19]. The forskolin contained in the plant can promote nerve repair by increasing cAMP concentrations. Studies on forskolin and some 50 derivatives of the compound indicated that the natural product was more active than its analogues. This is sequel to the belief that natural cures are biodegradable natural resources, safer than synthetic pharmaceuticals and more environmental friendly [20]. This assertion agrees with the reasons for synthesis and use of nanoparticles from natural sources as nanomedicines. In addition, nanoparticles are more active, stable, reliable and rational than their ordinary plant extracts or their other natural sources. The nanoparticles in evidential use includecopper, zinc, titanium [21], magnesium, gold [22], alginate (Ahmad et al., 2005) [23] and silver nanoparticles (Ag NPs) which have been proven to be the most effective against microbes such as bacteria, viruses and other eukaryotic microorganisms [24]. The gold nanoparticles (Au NPs) synthesized by decoction of powdered tea (Antigonon leptopus) leaf extract exhibited higher free radical scavenging and anti-human adenocarcinoma breast cancer (MCF-7) propensities with growth inhibitory concentration $\left(\mathrm{GI}_{50}\right)$ of $257.8 \mu \mathrm{g} / \mathrm{mL}$ than the tea leaf extract after $48 \mathrm{~h}$ [25]. Plectranthus barbatus (forskolin) nanoparticles e.g. Au NPs and Ag NPs can likely be made to improve the various pharmacological properties of Plectranthus barbatus enumerated above especially anticancer and antimicrobial activities respectively. In order to effectively estab- 
lish whether an herbal drug is effective or even safe, it is necessary to detect all the active chemicals that exist in a medicinal plant, as well as evaluate their toxicity and pharmacological effects. To this end, this study was carried out to establish the scientific basis for the traditional uses of this plant for safe treatment of pain and fever in Western Uganda.

\section{Materials and Methods}

\subsection{Preparation of Plant Extract}

The plant, Plectranthus barbatus was botanically authenticated by a botanist from Kampala International University-Western Campus, Ishaka, Bushenyi, Uganda. Fresh leaves of Plectranthus barbatus were then collected from Ishaka Town in the morning hours during the rainy season. The leaves were washed off soil particles, separated and air-dried under a shade and ground into fine powder. Extraction was by decoction to mimic traditional users of the herb. Five hundred and forty (540) grammes of the fine powder were weighed and dissolved in 1 Litre of distilled water in a beaker, then loaded and shaken on a shaker for 24 hours, then filtered through a filter paper and the filtrate concentrated over a water bath and evaporated to dryness at $40^{\circ} \mathrm{C}$ in a hot air oven to produce Plectranthus barbatus Aqueous Extract (PBAE). The procedure was repeated three times. The yields were then weighed and mean percentage yield calculated.

\subsection{Preliminary Phytochemical Screening}

The presence of phytochemical constituents in the aqueous extract was tested qualitatively following standard methods of [20] [26] and results were recorded as present $(+)$ or absent $(-)$. The details of the procedures for the test of saponins, tannins, alkaloids, terpenoids and essential oils were performed according to [20] [26] as follow:

\subsubsection{Saponins}

About $0.2 \mathrm{~g}$ of the extract was shaken with $5 \mathrm{~mL}$ distilled water and then heated to boil. Frothing indicated presence of saponins.

\subsubsection{Tannins}

Small quantity of the extract were mixed with water and heated on water bath then filtered. A few drops of $0.1 \%$ ferric chloride were added to the filtrate and observed for the presence of brownish green or blue-black coloration which indicated presence of tannins.

\subsubsection{Alkaloids}

About $0.5 \mathrm{~g}$ of the extract was stirred in $5 \mathrm{~mL}$ of $1 \%$ aqueous hydrochloric acid on a steam bath for 5 minutes. Two to three drops of Mayer's reagent was added by the side of the test tube. Turbidity or a white precipitate with this reagent indicated the presence of alkaloids. 


\subsubsection{Terpenoids}

About $0.2 \mathrm{~g}$ of the extract was dissolved in $5 \mathrm{~mL}$ of distilled water and filtered. This was then mixed with $2 \mathrm{~mL}$ of chloroform and concentrated sulphuric acid carefully added to form a layer. A reddish colouration at the interface indicated presence of terpenoids.

\subsubsection{Essential Oils}

About $0.2 \mathrm{~g}$ of the extract was dissolved in $5 \mathrm{~mL}$ of distilled water and filtered. Two $\mathrm{mL}$ of this was shaken with $0.2 \mathrm{~mL}$ of $2 \mathrm{M}$ sodium hydroxide and thereafter $2 \mathrm{~mL}$ of $2 \mathrm{M}$ dilute hydrochloric acid was added. Formation of a white precipitate indicated presence of essential oils.

\subsection{Laboratory Animal Acquisition and Maintenance}

Male and female Wistar rats weighing not less than $100 \mathrm{~g}$ were used. They were bred and housed in the Animal Facility Centre of the School of Pharmacy, KIU-WC. The animals were separated and kept for 10 days for acclimatization in a cage lined with wood shavings, maintained at room temperature with adequate ventilation and naturally illuminated environment with $12 \mathrm{~h}$ of light and $12 \mathrm{~h}$ of darkness. They were fed on standard diet (Nuvita Animal Feed Ltd, Jinja Uganda) and allowed access to clean drinking water ad libitum. The animals were treated according to the National Institute of Health Guide (NIHG) for the care and use of laboratory animals [27] and ethical guidelines for investigation of experimental pain in conscious animals [28].

\subsection{Evaluation of Acute Toxicity}

The acute safety of the leaf aqueous extract of Plectranthus barbatus was tested using Lorke's method of 1983 [29] as modified by [30]. Here, rats were used instead of mice. The rats were fasted for 18 hours before treatment. This method was implemented in 2 phases as follow:

Phase 1: Three (3) groups of three rats each were used $(\mathrm{n}=3)$. Plectranthus barbatus aqueous extract was administered orally in geometrical doses: Group A $1000 \mathrm{mg} / \mathrm{kg}$, Group B $3000 \mathrm{mg} / \mathrm{kg}$ and Group C $5000 \mathrm{mg} / \mathrm{kg}$. The treated rats were observed for three hours post administration for signs of toxicity. After 24 hours, no death was recorded thereby leading to initiation of Phase 2.

Phase 2: Three (3) groups of one rat each $(\mathrm{n}=1)$ were also given PBAE orally in geometrical doses for Group A $6000 \mathrm{mg} / \mathrm{kg}$, Group B $8000 \mathrm{mg} / \mathrm{kg}$ and Group C $10,000 \mathrm{mg} / \mathrm{kg}$. The rats were then observed for pharmacotoxic signs and mortality after 24 hours which were used as the index for acute toxicity [31]. The pharmacotoxic signs considered included: salivation, diarrhoea, piloerection, increased motor activity, arching, sedation, restlessness, sensitivity to sound and touch, gasping, cyanosis, bloody urine and oedema.

\subsection{Analgesic Activity Testing of PBAE}

Painful or noxious stimuli was inflicted on the rats by direct stimulation of pain 
receptors using two types of stimuli such as mechanical/thermal stimuli (tail-flick test) and chemical stimuli (formalin) induced pain.

\subsubsection{Tail-Flick Test}

The study of [32], subsequently modified for rats using hot water bath [33] [34] [35] [36] [37] was adopted with minor modifications for our local laboratory setting. The tail of the rat was marked $2 \mathrm{~cm}$ from the tip as the part that would be inserted into the hot water during the experiment. A baseline tail reaction response time (withdrawal of the tail from hot water within 3 seconds) was used to group the thirty rats into five groups of six animals each $(n=6)$. The rats were then treated with PBAE at oral doses of 100, 200 and $400 \mathrm{mg} / \mathrm{kg}$ as well as with morphine $(2 \mathrm{~mL} / \mathrm{kg}$, positive control) and distilled water $(10 \mathrm{~mL} / \mathrm{kg}$, negative control). The test was carried out by immersing the terminal $2 \mathrm{~cm}$ of the tail of the rat in a water bath heated and maintained at $55^{\circ} \mathrm{C} \pm 1^{\circ} \mathrm{C}$ (Memmert $\mathrm{GmbH}$ + Co.KG, D-91126 Schwabach FRG, Schutzart DIN EN 60529-Ip20, Germany). A thermometer was placed inside the water to monitor the temperature. The response latency between onset of immersion and withdrawal of the tail completely out of the water was recorded at 30 minutes and 60 minutes' intervals after treatment. A cut-off time of 6 seconds was used in order to prevent damage to the tail. The response of the extract and morphine $(2 \mathrm{~mL} / \mathrm{kg})$ treated groups of animals were compared with those of animals in the control group (distilled water, $10 \mathrm{~mL} / \mathrm{kg}$ ).

\subsubsection{Formalin-Induced Pain Test}

The method of [38] as modified by [39] was used for this study. Rats were grouped into five groups of five animals each $(n=5)$ using their weights and three groups were treated with oral doses of PBAE $100 \mathrm{mg} / \mathrm{kg}, 200 \mathrm{mg} / \mathrm{kg}$ and $400 \mathrm{mg} / \mathrm{kg}$ as well as another group with aspirin $100 \mathrm{mg} / \mathrm{kg}$ (positive control group) and last group distilled water $10 \mathrm{~mL} / \mathrm{kg}$ (negative control group). After 30 minutes, $0.05 \mathrm{~mL}$ of $2.5 \%$ formalin was injected subcutaneously into the sub-plantar surface of the left hind paw of the rats and the severity of the pain for both the control and test groups were observed in two phases. The first phase was every two minutes for the first ten minutes post formalin (representing the early phase referred to as aphasic pain) and the second phase was every 5 minutes starting from the $15^{\text {th }}$ minute post formalin to the $60^{\text {th }}$ minute (representing the late phase referred to as tonic pain). The severity of pain was scored using the following pain measurements: rat could bear weight on the injected paw by walking normally on it (0), light resting on the paw (1), elevation of the injected paw (2), licking or biting or grooming of the injected paw (3). The scores for each group were added up in each phase separately and the mean calculated.

\subsection{Antipyretic Activity (Effect on Yeast Induced Pyrexia)}

The modified method of [40], as modified for local laboratory setting by [41] was adopted. Rats were used for the study instead of mice. The test was per- 
formed by subcutaneous injection of the rats with $10 \mathrm{~mL} / \mathrm{kg}$ of $15 \%$ aqueous solution of yeast (Vahine Professional ${ }^{\circ}$, France) to induce pyrexia. Rectal temperature of each animal was taken before and 24 hours (h) after the yeast injection using digital clinical thermometer (Hartmann ${ }^{\circ}$, Germany). Animals that did not show a minimum increase of $0.5^{\circ} \mathrm{C}$ in temperature 24 hours after yeast injection were discarded. The selected 25 animals were grouped into $5(n=5)$ using their body temperatures and treated orally with $10 \mathrm{~mL} / \mathrm{kg}$ distilled water as negative control, extract (100, 200 and $400 \mathrm{mg} / \mathrm{kg}$ ) and $20 \mathrm{mg} / \mathrm{kg}$ of paracetamol (Glaxo Smithkline, London) as test animals. The rectal temperature of each animal was recorded again at $0.5 \mathrm{~h}, 1 \mathrm{~h}, 1.5 \mathrm{~h}, 2 \mathrm{~h}, 3 \mathrm{~h}$ and $4 \mathrm{~h}$ after treatment. Antipyretic effect was rated as the ability of test substances to reverse the induced pyrexia. Percentage reduction in body temperature of rats was calculated for the rats on one occasion using the control group temperatures as the reference and on second occasion using the zero $h$ temperature for each group as the group's own reference [42].

\subsection{Statistical Analysis}

Results were presented as mean values \pm Standard Error of Mean (SEM). Statistical significance and data comparisons between groups were done using the Student's t-test, repeated-measures ANOVA and Dunn's post hoc test. Values with $\mathrm{p}<0.05$ were considered significant.

\section{Results and Discussion}

\subsection{Yield of Extract Harvested}

Five hundred and forty (540) g of dry powder of Plectranthus barbatus leaves in 1 Litre of distilled water produced mean yield of $53.5 \mathrm{~g}$ of extract representing $9.9 \%$ of extract after drying.

\subsection{Phytochemical Analysis}

Phytochemical analysis of PBAE showed the presence of saponins, tannins, alkaloids, terpenoids and essential oils.

\subsection{Acute Toxicity Tests}

Oral administration of a maximum dose of $10,000 \mathrm{mg} / \mathrm{kg}$ of PBAE caused no deaths after 24 hours in any of the rats in either phase I or II implying that the $\mathrm{LD}_{50}$ was therefore estimated to be over $10,000 \mathrm{mg} / \mathrm{kg}$. Other pharmacotoxic effects observed such as motor activity alternating with sedation, piloerection, arching and loss of appetite were increased at the dose of 10,000 mg/kg.

\subsection{Analgesic Tests}

\subsubsection{Tail-Flick}

The thermal induced pain model (tail-flick method) test results were statistically significant $(\mathrm{p}<0.05)$ at $100 \mathrm{mg} / \mathrm{kg}$ within 30 minutes and at 100, 200 and 400 
$\mathrm{mg} / \mathrm{kg}$ doses within 60 minutes of the testing period as with $2 \mathrm{~mL} / \mathrm{kg}$ of the reference drug, morphine when compared to the negative control (distilled water), using the student $\mathrm{t}$-test. Repeated-measure ANOVA test showed significant $(\mathrm{p}<$ $0.05)$ differences between dose groups at 30 and 60 minutes of the test period. The Dunn's post hoc test displayed significant $(\mathrm{p}<0.05)$ differences in the pain inhibition effects between distilled water and other doses, between 100 and 200 $\mathrm{mg} / \mathrm{kg}$ and between 200 and $400 \mathrm{mg} / \mathrm{kg}$ dose groups of PBAE and between PBAE doses and morphine dose on the rats (Table 1).

\subsubsection{Formalin-Induced Pain Tests}

The Plectranthus barbatus extract exhibited a significant inhibition of pain induced by formalin. The results of this analgesic study revealed that 200 and $400 \mathrm{mg} / \mathrm{kg}$ doses of the extract exhibited significant $(\mathrm{p}<0.05)$ inhibition of pain induced by formalin, but a non-significant $(\mathrm{p}>0.05)$ effect by $100 \mathrm{mg} / \mathrm{kg}$ of extract. The inhibition was comparable with that of the reference drug, aspirin (100 mg/kg p.o), with the extract at $200 \mathrm{mg} / \mathrm{kg}$ showing a similar inhibition as aspirin, and the extract at $400 \mathrm{mg} / \mathrm{kg}$ exhibiting a superior activity to that of aspirin (Table 2). Repeated-measures and One-way ANOVA tests revealed significant $(\mathrm{p}<0.05)$ difference in pain inhibition between the negative control and PBAEs and aspirin at both early and late phases of formalin-induced pain. Dunn's post hoc test also showed significant $(\mathrm{p}<0.05)$ differences among the different doses of PBAE, between NC and PC at both early and late phases.

\subsubsection{Anti-Pyretic Test 1}

The results of the antipyretic study showed that the P. barbatus leaf aqueous extract had no significant effect on yeast-induced pyrexia, while the reference drug paracetamol significantly $(\mathrm{p}<0.05)$ reversed yeast-induced pyrexia when the test results were compared with the negative control (Student t-test). One-way ANOVA indicated significant $(\mathrm{p}<0.05)$ difference among dose groups of extracts, NC and PC $(\mathrm{p}=2 \mathrm{E}-05)$. Tukey's test also indicated significant $(\mathrm{p}<0.05)$ difference between paracetamol and NC and each of the doses of the extracts (Table 3).

\subsubsection{Anti-Pyretic Test 2}

Table 4 shows the results of the reduction in pyrexia induced by yeast when temperature at zero hour was used as the reference for comparison with other rectal temperature readings. Reduction in pyrexia exhibited by the animals followed an indefinite pattern both down the group and across the experimental times from $0.5 \mathrm{~h}$ to $4 \mathrm{~h}$. While the extracts did not record any significant reduction in pyrexia, the reference drug, paracetamol at $20 \mathrm{mg} / \mathrm{kg}$ completely and significantly $(\mathrm{p}<0.05)$ reversed the yeast induced pyrexia in the $2^{\text {nd }}, 3^{\text {rd }}$ and $4^{\text {th }}$ hours on comparison with negative control $(\mathrm{p}<0.05)$. One-way ANOVA exhibited significant $(\mathrm{p}<0.05)$ differences in body temperature reduction among the doses of the extracts, NC and PC. Tukey's test also exhibited significant ( $\mathrm{p}<$ 
0.05) differences in body temperature reduction between each of the extracts' doses and PC and between NC and PC (Table 4).

Table 1. Effect of the PBAE Leaves on Thermally Induced Pain in Rats (Tail-Flick Response Time).

\begin{tabular}{|c|c|c|c|c|c|}
\hline \multirow{2}{*}{ Treatment } & \multicolumn{5}{|c|}{ Tail response time (Seconds) } \\
\hline & $0 \min \left(\mathrm{T}_{0}\right)$ & $30 \min \left(\mathrm{T}_{1}\right)$ & $60 \min \left(\mathrm{T}_{2}\right)$ & $\mathrm{T}_{1}-\mathrm{T}_{0}$ & $\mathrm{~T}_{2}-\mathrm{T}_{0}$ \\
\hline \multicolumn{6}{|l|}{ Distilled water $10 \mathrm{ml} / \mathrm{kg}$} \\
\hline (Negative Control) & $1.14 \pm 0.04$ & $1.18 \pm 0.04^{\mathrm{a}}$ & $1.18 \pm 0.02$ & $0.45 \pm 0.04^{\mathrm{d}}$ & $0.04 \pm 0.04$ \\
\hline PBAE 100 mg/kg & $1.14 \pm 0.04$ & $1.49 \pm 0.10^{*}$ & $1.68 \pm 0.18^{\star, c}$ & $0.36 \pm 0.09^{*}$ & $0.55 \pm 0.18^{\star, \mathrm{e}}$ \\
\hline PBAE $200 \mathrm{mg} / \mathrm{kg}$ & $1.11 \pm 0.03$ & $1.13 \pm 0.05^{\mathrm{a}, \mathrm{b}}$ & $1.44 \pm 0.10^{*, \mathrm{c}}$ & $0.02 \pm 0.04^{\star, \mathrm{d}}$ & $0.33 \pm 0.11^{\star, \mathrm{e}}$ \\
\hline PBAE 400 mg/kg & $1.14 \pm 0.02$ & $1.21 \pm 0.05$ & $1.84 \pm 0.04^{*}$ & $0.06 \pm 0.03^{*}$ & $0.70 \pm 0.04^{\star, \mathrm{e}}$ \\
\hline \multicolumn{6}{|l|}{ Morphine $2 \mathrm{~mL} / \mathrm{kg}$} \\
\hline Positive Control) & $1.18 \pm 0.03$ & $1.31 \pm 0.07^{\mathrm{a}, \mathrm{b}}$ & $2.00 \pm 0.07^{\star, c}$ & $0.12 \pm 0.04^{\star, \mathrm{d}}$ & $0.81 \pm 0.09^{\star, \mathrm{e}}$ \\
\hline
\end{tabular}

$\mathrm{n}=6$, values were presented as mean \pm standard error of mean (S.E.M). ${ }^{*}: \mathrm{p}<0.05$ was considered significant when compared with negative control, (Student's t-test) and when inter- and intra-group comparisons were carried out. Repeated-measures ANOVA (Between groups p value $=0.0002$; Dunn's post hoc test (significant difference $={ }^{\mathrm{a}, \mathrm{b}, \mathrm{c}, \mathrm{d}, \mathrm{e}}$ at 30 and 60 minutes and their differences with zero minute temperature at $\mathrm{p}<0.05$ ).

Table 2. Effect of the PBAE Leaves on Chemically Induced Pain in Rats (Formalin Test).

\begin{tabular}{|c|c|c|c|c|}
\hline Treatment & Phase 1 & Inhibition (\%) & Phase 2 & Inhibition (\%) \\
\hline Distilled water $10 \mathrm{~mL} / \mathrm{kg}(\mathrm{NC})$ & $2.37 \pm 0.08^{\mathrm{a}, \mathrm{c}, \mathrm{d}}$ & - & $3.00 \pm 0.00^{\mathrm{e}, \mathrm{g}, \mathrm{h}}$ & - \\
\hline PBAE $100 \mathrm{mg} / \mathrm{kg}$ & $1.50 \pm 0.21^{\star, c, d}$ & 36.71 & $2.57 \pm 0.04^{*, \mathrm{f,h}}$ & 14.33 \\
\hline PBAE $200 \mathrm{mg} / \mathrm{kg}$ & $0.70 \pm 0.21^{\mathrm{a}, \mathrm{b}, \mathrm{c}}$ & 70.46 & $2.11 \pm 0.03^{\star, e, g, h}$ & 29.67 \\
\hline PBAE $400 \mathrm{mg} / \mathrm{kg}$ & $0.33 \pm 0.11^{\star, a, b, c}$ & 86.08 & $1.64 \pm 0.11^{\star, \mathrm{e}, \mathrm{f}, \mathrm{g}}$ & 45.33 \\
\hline Aspirin 100 mg/kg (PC) & $0.57 \pm 0.03^{*, \mathrm{a}, \mathrm{b}, \mathrm{d}}$ & 75.95 & $1.76 \pm 0.11^{*, \mathrm{e}, \mathrm{f}, \mathrm{h}}$ & 41.33 \\
\hline
\end{tabular}

$\mathrm{n}=6, \mathrm{NC}=$ Negative Control, PC $=$ Positive Control, values were presented as mean \pm standard error of mean (S.E.M). ${ }^{*}: \mathrm{p}<0.05$ was considered significant when compared with negative control, (Student's t-test) and when inter- and intra-group comparisons were carried out. Early phase: Repeated-measures ANOVA (Between groups $\mathrm{p}$ value $=1.573 \mathrm{E}-27$; One-way ANOVA p value $=1 \mathrm{E}-05$. Late phase: Repeated-measures ANOVA $($ Between groups $\mathrm{p}$ value $=1.044 \mathrm{E}-27$; One-way ANOVA $\mathrm{p}$ value $=1 \mathrm{E}-05$; Dunn's post hoc test (significant difference $=$ a, b,c,d,e,f,g among the doses of PBAE, PC and $\mathrm{NC}$ at both early and late phases of formalin-induced pain inhibition at $\mathrm{p}<0.05$ ).

Table 3. Effect of the PBAE on Yeast Induced Pyrexia in Rats (Anti-pyretic Test).

\begin{tabular}{|c|c|c|c|c|c|c|c|c|}
\hline \multirow{2}{*}{\multicolumn{2}{|c|}{$\begin{array}{l}\text { Treatment } \\
\text { Group BBT }\end{array}$}} & \multicolumn{7}{|c|}{ Mean Rectal Temperature $\left({ }^{\circ} \mathrm{C}\right)$ and $\%$ Reduction in Body Temperature of Rats } \\
\hline & & $0 \mathrm{~h}$ & $0.5 \mathrm{~h}$ & $1 \mathrm{~h}$ & $1.5 \mathrm{~h}$ & $2 \mathrm{~h}$ & $3 \mathrm{~h}$ & $4 \mathrm{~h}$ \\
\hline PBAE $100 \mathrm{mg} / \mathrm{kg}$ & $37.00 \pm 0.18$ & $38.02 \pm 0.15$ & $\begin{array}{c}38.68 \pm 0.31 \\
(-)^{\mathrm{a}}\end{array}$ & $\begin{array}{c}37.92 \pm 0.27 \\
(0.99)^{\mathrm{a}}\end{array}$ & $\begin{array}{c}37.92 \pm 0.30 \\
(-)^{\mathrm{a}}\end{array}$ & $\begin{array}{c}37.92 \pm 0.39 \\
(-)^{\mathrm{a}}\end{array}$ & $\begin{array}{c}37.56 \pm 0.20 \\
(-)^{\mathrm{a}}\end{array}$ & $\begin{array}{c}37.68 \pm 0.20 \\
(0.37)^{\mathrm{a}}\end{array}$ \\
\hline PBAE $400 \mathrm{mg} / \mathrm{kg}$ & $36.74 \pm 0.05$ & $37.86 \pm 0.16$ & $\begin{array}{c}38.08 \pm 0.32 \\
(0.42)^{\mathrm{a}}\end{array}$ & $\begin{array}{c}38.06 \pm 0.10 \\
(0.63)^{\mathrm{a}}\end{array}$ & $\begin{array}{c}37.74 \pm 0.19 \\
(-)^{\mathrm{a}}\end{array}$ & $\begin{array}{c}37.56 \pm 0.40 \\
(0.58)^{\mathrm{a}}\end{array}$ & $\begin{array}{c}37.32 \pm 0.36 \\
(0.48)^{\mathrm{a}}\end{array}$ & $\begin{array}{c}37.86 \pm 0.20 \\
(-)^{\mathrm{a}}\end{array}$ \\
\hline PCM 20 mg/kg (PC) & $37.16 \pm 0.15$ & $38.22 \pm 0.16$ & $\begin{array}{c}38.10 \pm 0.22 \\
(0.37)^{\mathrm{a}}\end{array}$ & $\begin{array}{c}37.12 \pm 0.17^{\star} \\
(3.08)^{\mathrm{a}}\end{array}$ & $\begin{array}{c}36.50 \pm 0.16^{*} \\
(3.13)^{\mathrm{a}}\end{array}$ & $\begin{array}{c}35.46 \pm 0.25^{\star} \\
(6.14)^{\mathrm{a}}\end{array}$ & $\begin{array}{c}35.28 \pm 0.19^{\star} \\
(5.92)^{\mathrm{a}}\end{array}$ & $\begin{array}{c}34.88 \pm \\
0.25^{\star}(7.77)^{\mathrm{a}}\end{array}$ \\
\hline
\end{tabular}

$\mathrm{n}=6,{ }^{\mathrm{a}}=$ Each value represents \% reduction of pyrexia in treated groups of rats using NC group temperature as the reference, DW $=$ Distilled Water, NC $=$ Negative Control, $\mathrm{PCM}=$ Paracetamol, $\mathrm{PC}=$ Positive Control, BBT: Basal Body Temperature, $\mathrm{M} \pm \mathrm{SEM}=$ values were presented as mean \pm standard error of mean, ${ }^{*}=$ Each value was considered significant at $\mathrm{p}<0.05$ when compared with NC (Student's t-test) and when inter- and intra-group comparisons were carried out (ANOVA). One-way ANOVA (Between groups p value $=2 \mathrm{E}-05$; Tukey's test $=$ significant difference among NC, paracetamol and each of PBAE doses at $\mathrm{p}<0.05)$. 
Table 4. Difference in Rectal temperature of Rats between $0 \mathrm{~h}$ and other respective Temperature Time Points ${ }^{\circ} \mathrm{C}$.

\begin{tabular}{|c|c|c|c|c|c|c|}
\hline Treatment & $0.5 \mathrm{~h}$ & $1 \mathrm{~h}$ & $1.5 \mathrm{~h}$ & $2 \mathrm{~h}$ & $3 \mathrm{~h}$ & $4 \mathrm{~h}$ \\
\hline DW $10 \mathrm{~mL} / \mathrm{kg}$ (NC) & $0.02 \pm 0.17$ & $0.00 \pm 0.21$ & $0.38 \pm 0.45$ & $0.28 \pm 0.20$ & $0.56 \pm 0.46$ & $0.24 \pm 0.23$ \\
\hline PBAE 100 mg/kg & $0.14 \pm 0.05$ & $0.46 \pm 0.16$ & $0.46 \pm 0.26$ & $0.46 \pm 0.39$ & $0.82 \pm 0.26$ & $0.70 \pm 0.18$ \\
\hline PBAE $200 \mathrm{mg} / \mathrm{kg}$ & $0.34 \pm 0.31$ & $0.12 \pm 0.12$ & $0.62 \pm 0.33$ & $0.56 \pm 0.21$ & $0.06 \pm 0.10$ & $0.08 \pm 0.10$ \\
\hline PBAE $400 \mathrm{mg} / \mathrm{kg}$ & $0.04 \pm 0.19$ & $0.18 \pm 0.15$ & $0.10 \pm 0.35$ & $0.28 \pm 0.35$ & $0.52 \pm 0.48$ & $0.18 \pm 0.31$ \\
\hline PCM 20 mg/kg (PC) & $0.12 \pm 0.17$ & $1.10 \pm 0.28^{\star}$ & $1.72 \pm 0.28$ & $2.76 \pm 0.38^{\star}$ & $2.94 \pm 0.27^{\star}$ & $3.34 \pm 0.35^{\star}$ \\
\hline
\end{tabular}

$\mathrm{n}=6, \mathrm{DW}=$ Distilled Water, $\mathrm{NC}=$ Negative Control, $\mathrm{PCM}=$ Paracetamol, $\mathrm{PC}=$ Positive Control, $\mathrm{BBT}=\mathrm{Basal}$ Body Temperature, $\mathrm{M} \pm \mathrm{SE} . \mathrm{M}=$ values were presented as mean \pm standard error of mean, ${ }^{*}=$ Each value was considered significant at $\mathrm{p}<0.05$ when compared with NC (Student's t-test) and when inter- and intra-group comparisons were carried out (ANOVA). One-way ANOVA (Between groups p value $=2.142 \mathrm{E}-09$; Tukey's test $=$ significant difference between paracetamol and $\mathrm{NC}$ and each of the extract doses at $\mathrm{p}<0.05$ ).

\section{Discussion}

This study was carried out to establish the scientific basis for the traditional uses of this plant for safe and effective treatment of pain and fever in Western Uganda. The yield of the extract realized from the leaves of Plectranthus barbatus was good at approximately $10 \%$. The method of extraction was by decoction using water according to the local practice of the traditional healers and other users of the herb.

The qualitative phytochemical tests done on PBAE showed positive results to terpenoids, tannins, saponins, alkaloids and essential oils. These phytochemical constituents could be said to have contributed to the various activities of the plant. The main phytochemical constituents of Plectranthus barbatus confirmed by research are terpenoids especially 8,13 -epoxy-labd-14-en-11-one diterpenoids (Forskolin, formerly coleonol) [17]. Terpenoids have been found to have analgesic, antiseptic, stimulant and diuretic properties, among other uses [20]. Tannins and saponins are probably implicated in the plant's known analgesic properties. The main therapeutic action of tannins is astringent effect as it forms protective layer resistant to disease. Tannins equally effect healing by protecting the affected areas treated with them as well as reducing inflammation at the same time. This accentuates the fact for its use in compress for cuts and wounds, haemorrhoids, varicose veins and in medicine for diarrhoea, catarrh, heavy menstrual flows and inflammatory conditions of the digestive tract [20]. Saponins are glycosides which form bubbles when mixed with water. They exert a wide spectrum of therapeutic actions in the body and they include anti-inflammatory, expectorant, diuretic, anti-malarial and haemolytic effects on red blood cells (toxic) when injected into the blood stream and comparatively harmless when taken orally [20]. Terpenoids are oxygenated derivatives of hydrocarbons found in volatile plant origin accounting for analgesic, antiseptic, stimulant, carminative, diuretic, anthelminthic, anti-rheumatic and counter-irritant properties in the plant [20]. Today, several studies on tuberous extracts of Plectranthus $s p$ revealed presence of minor diterpenoids such as deactylforskolin, 9-deoxyforskolin, 1,9-deoxyforskolin, 1,9-dideoxy-7-deacetylforskolin in addition to forskolin 
(7-acetoxy-8, 13-epoxy-1,6,9-trihydroxylabd-14-en-11-one) [43], most of which have the same or less level of pharmacological activities than forskolin.

Acute toxicity tests indicated that the plant has a high median lethal dose $\left(\mathrm{LD}_{50}\right)$ of more than $10,000 \mathrm{mg} / \mathrm{kg}$ suggesting that the drug is generally safe being consistent with its popular traditional use. However, other pharmacotoxic effects were observed including increased motor activity, sedation, piloerection, arching and loss of appetite at the dose of $10,000 \mathrm{mg} / \mathrm{kg}$ (Category IV classification) with no death [44].

Pain modulation refers to the function of the neural cells to inhibit, reduce or dampen the intrinsic modulatory activity of the central and peripheral nervous system, thus reducing the painful stimuli usually localized in certain body regions [45]. The results were not statistically significant in reaction time of tail flick test at 30 minutes but statistically significant at 60 minutes. The tail flick test is a standard method for investigating nociception and analgesia according to [32]; that measures the response to a brief, noxious stimulus which appears to be spinal reflex that is modulated by supraspinal inhibitory mechanisms. Thermal painful stimuli like tail flick test are known to be selective for centrally acting analgesics [46]; indicative of morphine-like effect but not peripherally acting analgesic drugs [47] [48]. In this study, morphine, a centrally acting analgesic drug as well as $P$. barbatus extract produced an inhibitory effect on the nociceptive response in the tail flick test at 60 minutes. The presence of potent effect from this test therefore suggests that the apparent analgesic action of $P$. barbatus extract may be mediated through centrally mediated mechanisms, constituting morphine-like activity.

In this study, the extract caused a dose-dependent decrease in the number of times of licking of the formalin injected left hind paw by the rats, also depicting an analgesic potency in Plectranthus barbatus. The results demonstrated that the aqueous extract of $P$. barbatus showed significant $(\mathrm{p}<0.05)$ and dose dependent anti-nociceptive responses to chemical stimuli in both phases 1 and 2 of the formalin test in rats. The experimental models were chosen in such a way that the existence of both centrally and peripherally mediated pain relief could be measured. Formalin test is a valid and reliable biphasic model which measures pain of both neurogenic (first phase) and of inflammatory origin (second phase). The first phase (aphasic) (0 - 10 minutes) is as a result of direct stimulation of nociceptors and measures centrally mediated effects and is insensitive to anti-inflammatory agents. The second phase (tonic) (15 - 60 minutes) is dependent upon peripheral inflammation and changes in central procession due to chemical inflammatory mediators released from damaged cells like histamine, prostaglandins, serotonin and bradykinins [39] [49] [50]. This test, therefore, measures the response to a long lasting nociceptive stimulus similar to clinical pain and is recommended as a tool in basic pain research for studying the mechanisms of analgesic agents because of its connection to tissue injury [39]. Centrally acting drugs like opioids inhibit both phases equally while peripherally acting drugs like aspirin only inhibit the late phase. The late phase seems to be an in- 
flammatory response with inflammatory pain that can be inhibited by anti-inflammatory drugs [51]. An analogue of forskolin and naturally occurring component of P. barbatus known as 1,9-dideoxyforskolin was found to exhibit anti-inflammatory effect in carrageenan-induced rat paw oedema test, croton oil-induced rat ear inflammation test and adjuvant-induced arthritis test in rats at $\mathrm{ED}_{50}$ values of $2.2 \mathrm{mg} / \mathrm{kg} / \mathrm{i}$. p., $1.6 \mathrm{mg} / \mathrm{ear}$, and $3.0 \mathrm{mg} / \mathrm{kg} / \mathrm{i} . \mathrm{p}$., respectively. Also, 1,9-dideoxyforskolin was found to have an analgesic effect with an $\mathrm{ED}_{50}$ of $9.0 \mathrm{mg} / \mathrm{kg} / \mathrm{s.c}$. by using the acetic acid induced writhing test in mice [10]. This is probably by inhibition of prostaglandin release [52] through inhibition of cyclooxygenase in peripheral tissues thereby interfering with the mechanism of transduction and pain mediation in primary afferent nociceptors [53].

The study also determined the anti-pyretic activity of aqueous extract of $P$. barbatus against yeast induced pyrexia through inhibition of synthesis of prostaglandins. This method is used to screen agents for anti-pyretic effect [40]. The $P$. barbatus extract produced some marked levels of anti-pyresis especially at 100 $\mathrm{mg} / \mathrm{kg}$ with no significant effect on pyrexia induced by yeast, while the reference drug, paracetamol reversed yeast-induced fever beyond the initial rectal temperature. This means that the extract could not inhibit completely synthesis of prostaglandins unlike paracetamol that displayed complete reversal of pyresis thereby attesting to the fact that prostaglandin synthesis was completely blocked by paracetamol. The affirmed analgesic significant activity of $P$. barbatus on tail flick and formalin induced pain tests and marginally non-significant anti-pyretic effect on yeast induced pyrexia may be responsible for the plant's analgesic and anti-pyretic properties attributable to its popular and legendary folkloric use in the treatment of pain and fever.

\section{Conclusion and Recommendations}

From the fore-going results, the conclusion on the study suggests that the aqueous leaf extract of Plectranthus barbatus contains specific phytochemicals such as terpenoids, saponins, tannins, alkaloids and essential oils; and has a potent dose dependent analgesic activity, no appreciable anti-pyretic activity and can be regarded as a safe medicinal plant for traditional use with remote pharmacotoxic manifestations at very high dose. We consequently recommend fractionation, isolation, structural elucidation of the active analgesic principles and production of nanoparticles of the active principles to facilitate their activities to obtain new effective analgesic drug identities from the Ugandan Plectranthus barbatus.

\section{Acknowledgements}

Our acknowledgement goes to KIU-WC for providing us the space and some equipment to carry out the work and to Mr. Ronald Kizza, a laboratory assistant in the Department of Pharmacology of School of Pharmacy, Kampala International University, Western Campus, Ishaka, Bushenyi for animal care and provi- 
sion of all-time assistance in these laboratories.

\section{Ethical Approval}

Ethical approval was sought and given by Kampala International University's School of Pharmacy Research Committee. These clearances enabled us to use the plants and the animals for this research.

\section{Authors' Contributions}

This study was conducted by the authors together in the following ways: JOCE initiated the study. Authors JOCE, GNK, AAA, JKT and JCE collected the data. Authors JOCE, GNK, SSD, AGO and JKT designed the study, wrote and corrected the protocol. Authors JKT, GNK, BEU and JOCE wrote the protocol and the first draft of manuscript, searched for literature, analysed the data, read through the data and made corrections. Authors JKT, SSD, GNK and JOCE managed the experimental processes, read through and made corrections to the manuscript draft. Authors JCE, AGO, AAA and BEU read through and made corrections to the manuscript draft. All authors read and approved the manuscript for publication.

\section{Consent}

Written consent was sought and secured from the Kampala International University School of Pharmacy Research Laboratories, Ishaka, Bushenyi where the animals were kept.

\section{Consent to Publish}

The authors consented to publishing of this article.

\section{Conflicts of Interest}

There is no conflict of interest among the authors. The fund used to carry out this work was solely contributed by the authors.

\section{References}

[1] World Health Organization (2002) Traditional Medicine: Growing Needs and Potential. WHO Policy Perspectives on Medicines. World Health Organization, Geneva, 1-6.

[2] Sidigia, I., Nyaigotti-Chacha, C. and Kanunah, M.P. (1995) Traditional Medicine in Africa. East African Educational Publishers, Nairobi.

[3] World Health Organization (2003) Traditional Medicine.

[4] Scheinman, D. (2002) The Ancient and Modern Worlds Unite to Fight HIV/AIDS in Tanga, Tanzania. Merck, Science in Africa On-Line Magazine.

[5] Kala, C.P., Farooquee, N.A. and Dhar, U. (2004) Prioritization of Medicinal Plants on the Basis of Available Knowledge, Existing Practices and Use Value Status in Uttaranchal, India. Journal of Biodiversity and Conservation, 13, 453-469. https://doi.org/10.1023/B:BIOC.0000006511.67354.7f 
[6] Kamatenesi, M.M. and Bukenya-Ziraba, R. (2002) Ethnobotanical Survey Methods to Monitor/Assess Sustainable Harvesting of Medicinal Plants in Uganda. In: Maunder, M., Clubbe, C., Hankamer, C. and Groves, M., Eds., Darwin Manual-Plant Conservation Techniques for the Tropics, Royal Botanic Gardens, Kew, 469-482.

[7] Duke, J.A. (2002) Handbook of Medicinal Herbs. 2nd Edition, CRC Press, New York, $870 \mathrm{p}$.

[8] Hanelt, P. and Buttner, R. (2001) Mansfeld's Encyclopedia of Agricultural and Horticultural Crops. Springer, Berlin, New York, Vol. 6v, 3645 p. https://trove.nla.gov.au/version/46526235

[9] de Padua, L.S., Bunyapraphatsara and Lmmens (Eds.) (1999) Medicinal and Poisonous Plants 1. Plant Resources of South-East Asia (PROSEA). Leiden/Wageningen, Backhuys/PROSEA. Bogor, PROSEA, 1999, Vo. 12, 711.

[10] Alasbahi, R. and Melzig, M.F. (2010b) Plectranthus barbatus. A Review of Phytochemistry, Ethnobotanical Uses and Pharmacology Part 2. Planta Medica, 76, 753-765. https://www.researchgate.net/deref/http:/www.ncbi.nlm.nih.gov/pubmed/20178070

[11] Lakshmanan, G.M.A., Manikandan, S. and Panneerselvam, R. (2013) Plectranthus forskohlii (Wild) Briq. (Syn:Coleus forskohlii) - A Compendium on Its Botany and Medicinal Uses. International Journal of Research in Plant Science, 4, 72-80. http://www.urpjournals.com

[12] Alasbahi, R. and Melzig, M.F. (2010a) Plectranthus barbatus. A Review of Phytochemistry, Ethnobotanical Uses and Pharmacology Part 1. Planta Medica, 76, 653-661.

https://www.researchgate.net/deref/http:/www.ncbi.nlm.nih.gov/pubmed/20178070

[13] Yashaswini, S. and Vasundhara, M. (2011) Coleus (Plectranthus barbatus) - A Multipurpose Medicinal Herb. International Research Journal of Pharmacy, 2, 47-58. http://www.irjponline.com

[14] Suddee, S., Paton, A.J. and Parnell, J.A.N. (2004) A Taxonomic Revision of Tribe Ocimeae Dumort. (Lamiaceae) in Continental South East Asia II. Plectranthinae. Kew Bulletin, 59, 379-414. https://doi.org/10.2307/4110950

[15] De Souza, N.J., Dohadwalla, A.N. and Reden, J. (1983) Forskolin: A Labdane Diterpenoid with Anti-Hypertensive, Positive Inotropic, Platelet Aggregation Inhibitory, and Adenylate Cyclase Activating Properties. Medicinal Research Reviews, 3, 201-219. https://doi.org/10.1002/med.2610030205

[16] Bhat, S.V., Dohadwalla, A.N., Bajwa, B.S., Dadkar, N.K., Dornauer, H. and De Souza, N.J. (1983) The Antihypertensive and Positive Inotropic Diterpene Forskolin: Effects of Structural Modifications on Its Activity. Journal of Medicinal Chemistry, 26, 486-492. https://doi.org/10.1021/jm00358a006

[17] Dubey, M.P., Srimal, R.C., Nityanand, S. and Dhawan, B.N. (1981) Pharmacological Studies on Coleonol, a Hypotensive Diterpene from Coleus forskohlii. Journal of Ethnopharmacology, 3, 1-13. https://doi.org/10.1016/0378-8741(81)90010-6

[18] Yamashita, A., Takashita, T. and Ishihara, T. (2004) Antiobesity Agents and Food, Beverage, and Medical Compositions Containing Bergenin and Forskolin and/or Astilbin. Japanese Patent JP 2004091464 A.

[19] Arnarson, A. (2017) Does Forskolin Actually Work? An Evidence-Based Review. Newsletter Healthline. https://www.healthline.com/nutrition/forskolin-review

[20] Trease, G.E. and Evans, W.C. (1989) Textbook of Pharmacognosy. 13th Eidtion, Balliere Tindall, London, 81-90, 269-275, 300. 
[21] Retchkiman-Schabes, P.S., Canizal, G., Becerra-Herrera, R., Zorrilla, C., Liu, H.B. and Ascencio, J.A. (2006) Biosynthesis and Characterization of Ti/Ni Bimetallic Nanoparticles. Optical Materials, 29, 95-99. https://doi.org/10.1016/j.optmat.2006.03.014

[22] Gu, H., Ho, P.L., Tong, E., Wang, L. and Xu, B. (2003) Presenting Vancomycin on Nanoparticles to Enhance Antimicrobial Activities. Nano Letters, 3, 1261-1263. https://doi.org/10.1021/nl034396z

[23] Ahmad, Z., Pandey, R., Sharma, S. and Khuller, G.K. (2005) Alginate Nanoparticles as Antituberculosis Drug Carriers: Formulation Development, Pharmacokinetics and Therapeutic Potential. Indian Journal of Chest Diseases and Allied Sciences, 48, 171-176.

[24] Gong, P., Li, H., He, X., Wang, K., Hu, J. and Tan, W. (2007) Preparation and Antibacterial Activity of $\mathrm{Fe}_{3} \mathrm{O}_{4} @ \mathrm{Ag}$ Nanoparticles. Nanotechnology, 8, 604-611.

[25] Balasubramani, G., Ramkumar, R., Krishnaveni, N., Pazhanimuthu, A., Natarajan, T., Sowmiya, R. and Perumal, P. (2015) Structural Characterization, Antioxidant and Anticancer Properties of Gold Nanoparticles Synthesized from Leaf Extract (Decoction) of Antigonon leptopus Hook. \& Arn. Journal of Trace Elements in Medicine and Biology, 30, 83-89. https://doi.org/10.1016/j.jtemb.2014.11.001

[26] Harbourne, J.B. (1998) Phytochemical Methods. A Guide to Modern Techniques of Analysis. 3rd Edition, Chapman and Hall, London.

[27] National Institute of Health (1996) National Institute of Health Guide for the Care and Use of Laboratory Animals. National Academic Press, NIH Publication, No. 23-83.

[28] Zimmermann, M. (1983) Ethical Guidelines for Investigation of Experimental Pain in Conscious Animals. Pain, 16, 109-110. https://doi.org/10.1016/0304-3959(83)90201-4

[29] Lorke, D. (1983) A New Approach to Practical Acute Toxicity Testing. Archive of Toxicology, 54, 275. https://doi.org/10.1007/BF01234480

[30] Ezeonwumelu, J.O.C., Matuki, E.K., Ajayi, A.M., Okoruwa, A.G., Tanayen, J.K., Adiukwu, C.P., Goji, A.D.T., Dare, S., Okonkwo, C.O. and Byarugaba, F. (2013) Phytochemical Screening, Acute Toxicity and Analgesic Properties of Aqueous Extract of Flueggea virosa's Root in Rats. Ibnosina Journal of Medicine and Biomedical Sciences, 5, 15-21. https://doi.org/10.4103/1947-489X.210519

[31] Adzu, B. and Haruna, A.K. (2007) Studies on the Use of Zizyphus Sphina-Chisti against Pain in Rats and Mice. African Journal of Biotechnology, 6, 1317-1324.

[32] D'Armour, F.E. and Smith, D.L. (1941) A Method for Determining Loss of Pain Sensation. Journal of Pharmacology and Experimental Therapeutics, 72, 74-79.

[33] Janssen, P.A.J., Niemegeers, C.J.E. and Dony, J.G.H. (1963) The Inhibitory Effect of Fentanyl and Other Morphine-Like Analgesic on the Warm Water Induced Tail Withdrawal Reflex in Rats. Arzneimittel-Forschung, 6, 502-507.

[34] Asongalem, E.A., Foyet, H.S., Ekobo, S., Folefoc, G.N., Dimo, T. and Kamchouing, P. (2004a) Anti-Inflammatory, Lack of Central Analgesia and Anti-Pyretic Properties of Acanthus montanus (Ness) T Anderson. Journal of Ethnopharmacology, 95, 63-68.

[35] Asongalem, E.A., Foyet, H.S., Ngogang, J., Folefoc, G.N., Dimo, T. and Kamchouing, P. (2004b) Analgesic and Anti-Inflammatory Activities of Ergeron floribundus. Journal of Ethnopharmacology, 91, 301-308.

[36] Rabanal, R.M., Bonkanka, C.X., Hernandez-Perez, M. and Sanchez-Mateo, C.C. 
(2005) Analgesic and Topical Anti-Inflammatory Activity of Hypericum canriense L. and Hypericum glandulosum Ait. Journal of Ethnopharmacology, 96, 591-596. https://doi.org/10.1016/j.jep.2004.10.013

[37] Sanchez-Mateo, C.C., Bonkanka, C.X., Hernandez-Perez and Rabanal, R.M. (2006) Evaluation of Analgesic and Topical Anti-Inflammatory Effects of Hypericum reflexum L. Fil. Journal of Ethnopharmacology, 107, 1-6. https://doi.org/10.1016/j.jep.2006.01.032

[38] Dubuission, D. and Dennis, S.G. (1977) The Formalin Test: A Quantitative Study of the Analgesic Effect of Morphine, Meperidine, and Brain Stem Simulation in Rats and Cats. Pain, 4, 161-174. https://doi.org/10.1016/0304-3959(77)90130-0

[39] Tjolsen, A., Berge, O.G., Hunskaar, S., Rosland, J.H. and Hole, K. (1992) The Formalin Induced Test: An Evaluation of the Method. Pain, 51, 5-14. https://doi.org/10.1016/0304-3959(92)90003-T

[40] Al-Ghamdi, M.S. (2001) The Anti-Inflammatory, Analgesic and Antipyretic Activity of Nigella sativa. Journal of Ethnopharmacology, 76, 45. https://doi.org/10.1016/S0378-8741(01)00216-1

[41] Adzu, B., Amos, S., Dzarma, S., Muazzam, I. and Gamaniel, K. (2002b) Pharmacological Evidence Favouring the Folkloric Use of Diospyrosmespiliformis Hochst in the Relief of Pain and Fever. Journal of Ethnopharmacology, 82, 191-195.

[42] Ezeonwumelu, J.O.C., Omar, A.N., Ajayi, A.M., Okoruwa, A.G., Tanayen, J.K., Kiplagat, D.M., Okpanachi, O.A., Abba, S., Ezekiel, I., Onchweri, A.N., Okonkwo, C.O and Byarugaba, F. (2012) Phytochemical Screening, Acute Toxicity, Anti-Inflammatory and Antipyretic Studies of Aqueous Extract of the Root of Flueggea virosa (Roxb. ex Willd.) in Rats. International Journal of Pharmacy and Biomedical Sciences, 3, 128-135.

[43] De Souza, N.J. and Shah, V. (1988) Forskolin-An Adenylatecyclase Activating Drug from an Indian Herb. Economic and Medicinal Plant Research, 2, 1-16.

[44] Wanda, M.H., Colin, G.R. and Mathew, A.W. (2002) Handbook of Toxicologic Pathology. 2nd Edition, Academic Press, Cambridge.

[45] Turk, D.C. and Rudy, T.E. (1988) Toward an Empirically Derived Taxonomy of Chronic Pain Patients: Integration of Psychological Assessment Data. Journal of Consulting and Clinical Psychology, 56, 233-238. https://doi.org/10.1037/0022-006X.56.2.233

[46] Ramabadran, K., Bansinath, M., Turndorf, H. and Puig, M.M. (1989) Tail Immersion Test for the Evaluation of a Nociceptive Reaction in Mice: Methodological Consideration. Journal of Pharmacology and Methods, 21, 21-31. https://doi.org/10.1016/0160-5402(89)90019-3

[47] Chau, T.T. (1989). Analgesic Testing in Animal Models. In: Chang, J.Y. and Lewis, A.J., Eds., Pharmacological Methods in the Control of Inflammation, Liss, A.R. Inc., New York, 195-212.

[48] Domer, F. (1990) Characterization of the Analgesic Activity of Ketorolac in Mice. European Journal of Pharmacology, 177, 127-135. https://doi.org/10.1016/0014-2999(90)90262-5

[49] Dawes, J.M., Anderson, D.A., Bennett, D.L., Bevan, S. and McMahon, S.B. (2013) Inflammatory Mediators and Modulators of Pain. Wall and Melzack's Textbook of Pain, 6, 48-67.

[50] Murray, C.W., Porreca, F. and Cowan, A. (1988) Methodological Refinements to the Mouse Paw Formalin Test: An Animal Model of Tonic Pain. Journal of Phar- 
macological Methods, 20, 175-186. https://doi.org/10.1016/0160-5402(88)90078-2 https://Arizona.pure.elsevier.com/en/publications/methological-refinements-to-the -mouse-paw-formalin-test-an-anim

[51] Hunskaar, S. and Hole, K. (1987) The Formalin Test in Mice: Dissociation between Inflammatory and Non-Inflammatory Pain. Pain, 30, 103-114. https://doi.org/10.1016/0304-3959(87)90088-1

[52] Fawad, K., Ul Islam, N., Subhan, F., Shahid, M. and Ahmad, N. (2018) Novel Hydroquinone Derivatives Alleviate Algesia, Inflammation and Pyrexia in the Absence of Gastric Ulcerogenicity. Tropical Journal of Pharmaceutical Research, 17, 53. https://doi.org/10.4314/tjpr.v17i1.9

[53] Seibert, K., Zhang, Y., Leahy, K., Hauser, S., Masferrer, J. and Isakson, P. (1997) Distribution of Cox-1 and Cox-2 in Normal and Inflamed Tissues. In: Honn, K.V., Nigam, S. and Marnett, L.J., Eds., Eicosanoids and Other Bioactive Lipids in Cancer, Inflammation and Radiation Injury 2, Advances in Experimental Medicine and Biology, Vol. 400, Springer, Boston. 